\title{
ENCÍCLICAS RERUM NOVARUM E CENTESIMUS ANNUS : UMA ANÁLISE DISCURSIVA SOBRE A QUESTÃO DO TRABALHO
}

\author{
Luzimare Almeida Piloto* \\ Edvânia Gomes da Silva*
}

RESUMO: Neste artigo, objetivamos verificar quais discursos sobre trabalho encontram-se materializados nas encíclicas Rerum Novarum e Centesimus Annus. Partimos da seguinte hipótese: a Centesimus Annus, escrita em 1991, que homenageia a Rerum Novarum, promulgada em 1891, retoma discursos acerca do trabalho materializado nesta última e atualiza esses discursos por meio de um jogo entre memória e acontecimento. Apresentamos um levantamento acerca das concepções de acontecimento e de memória discursiva, conforme proposta de Pêcheux (1983a, 1983b). Ao longo da discussão teórica e das análises, retomamos também conceitos de Marx e Engels (1948); Scherer e Taschetto (2005); e Terra (1991).

PALAVRAS-CHAVE: Discurso Religioso. Encíclicas. Memória. Trabalho.

\section{Introdução}

Neste artigo, investigamos quais discursos sobre o trabalho encontram-se materializados em dois importantes documentos da Igreja Católica: a encíclica Rerum Novarum (RN), primeira a tratar da questão do trabalho (especificamente sobre os operários), datada de 15 de maio de 1891 e escrita pelo Papa Leão XIII, no quarto ano do seu pontificado ${ }^{1}$,

\footnotetext{
* Mestre em Linguística pela Universidade Estadual do Sudoeste da Bahia (Uesb). Professor auxiliar da Universidade do Estado da Bahia (Uneb).

** Doutora em Linguística pela Universidade Estadual de Campinas (Unicamp). Pós-doutora em Linguística e Mestrado em Linguística (Unicamp). Professora Titular da Universidade Estadual do Sudoeste da Bahia (Uesb), onde leciona na Graduação em Letras e no Programa de Pós-Graduação em Memória: Linguagem e Sociedade e no Programa de Pós-Graduação em Linguística.
}

${ }^{1}$ O pontificado de Leão XIII ocorreu entre os anos de 1878 a1903. 
a qual surgiu no momento de plena efervescência das ideias comunistas e inaugurou uma série de documentos sobre questões sociais na Igreja Católica; e a encíclica Centesimus Annus $(\mathrm{CA})^{2}$, assinada pelo Papa João Paulo II, em $1^{\circ}$ de maio de1991, a qual presta homenagem a RN no ano do seu centenário, e que foi promulgada pouco tempo após a queda do Muro de Berlin, em 9 de novembro de 1989, evento considerado por alguns discursos como símbolo da derrocada do comunismo. Tais documentos fazem parte da Doutrina Social da Igreja (DSI), cujo principal objetivo é fixar princípios, critérios e diretrizes gerais a respeito da sua organização social e política.

Para essa investigação, formulamos a seguinte hipótese: a encíclica Centesimus Annus, que homenageia a Rerum Novarum no ano do seu centenário, reatualiza efeitos de sentido materializados na encíclica homenageada e atualiza esses efeitos por meio de um jogo entre memória e acontecimento. Nas análises, recorremos aos trabalhos de Pêcheux (1983a, 1983b), principalmente em relação aos conceitos de acontecimento e de memória. Para fundamentar teoricamente este artigo, recorremos, ainda, a alguns conceitos de Marx e Engels (1948), Scherer e Taschetto (2005) e Terra (1991).

\section{Estrutura e acontecimento na relação com a memória discursiva}

Partindo do ponto de vista Pecheutiano, definimos o discurso como uma relação entre estrutura e acontecimento. Nessa perspectiva, o discurso se estrutura na instabilidade produzida pela tensão, pelo conflito e o acontecimento, que surge na relação entre memória e atualidade, surge como elemento imprescindível na/para produção dos efeitos de sentido $^{3}$.

Pêcheux (1983a) chama a atenção para a possibilidade de se conceber o discurso como a relação entre "língua", que é estrutura, pois é constituída por signos estruturais,

\footnotetext{
${ }^{2}$ Utilizamos nas citações diretas deste artigo, que estão em português europeu, as siglas $\mathrm{RN}$ e CA conforme consta em vários documentos da Igreja Católica referentes a essas duas encíclicas.
}

${ }^{3}$ Para a Escola Francesa de Análise de Discurso, o sentido é sempre um efeito. 
que nascem da relação entre significado e significante, mas que também é equívoca e, portanto, está aberta à relação entre estruturação e desestruturação; e "processos discursivos", os quais se dão em meio às relações histórico-ideológicas.

O autor trata da relação entre os universos logicamente estabilizados, para os quais não são possíveis as derivas de sentido, e as formulações irremediavelmente equívocas, as quais se constituem pelo jogo desestabilização/reestabilização. Neste sentido, analisa a relação entre descrição e interpretação, buscando mostrar as diferenças entre as formas de fazer científico que se constituem com base nos universos logicamente estabilizados, como é o caso da física, e aquelas que atuam sobre o campo da interpretação e, portanto, sobre o campo das formulações irremediavelmente equívocas, como é o caso da Análise de Discurso.

Essa possibilidade de desestruturação-reestruturação que marca a própria constituição do discurso também é abordada por Pêcheux (1983b) em O papel da memória. Na referida obra, o autor trata da memória, considerando os sentidos entrecruzados da memória mítica; da memória social, inscrita em práticas; e da memória constituída pelo historiador. Ele caracteriza a linguística como uma disciplina de representação em relação às disciplinas de interpretação, como é o caso da história, que, por sua vez, está relacionada à memória. Nessa perspectiva, a desestruturação-reestruturação pode ser vista justamente como aquilo que relaciona memória e atualidade.

Segundo o autor, o acontecimento inscrito no espaço da memória gera uma tensão contraditória presente sob uma dupla forma-limite: i) a do "acontecimento que escapa à inscrição, que não chega a se inscrever"; e ii) a do "acontecimento que é absorvido na memória como se não tivesse acontecido" (PÊCHEUX, 1983b, p. 50). Ainda segundo Pêcheux, a memória discursiva é, portanto, aquilo que, mediante um texto que surge enquanto acontecimento a ler, vem restabelecer os implícitos, ou seja, os pré-construídos, elementos citados e relatados dos quais sua leitura necessita. Trata-se, nas palavras do autor, da "condição do legível em relação ao próprio legível" (PÊCHEUX, 1983b, p. 52). A partir 
dessa definição, surge uma questão: "saber onde residem esses famosos implícitos, que estão 'ausentes por sua presença”' (PÊCHEUX, 1983b, p. 52).

A resposta acerca da questão dos implícitos está na regulamentação ${ }^{4}$ sob a forma de remissões, de retomadas e de efeitos de paráfrase. Essa regulamentação, ainda segundo Pêcheux (1983b, p. 52), que se baseia nos conceitos de Achard, "é sempre suscetível de ruir sob o peso do acontecimento discursivo novo, que vem perturbar a memória".

Scherer e Taschetto (2005), ao tratarem da memória discursiva, com a qual trabalha Pêcheux, defendem que,

[...] se situarmos a memória do lado, não da repetição, mas da regularização, então ela se situaria em uma oscilação entre o histórico e o linguístico, na sua suspensão em vista de um jogo de forças de fechamento que o autor social ou o analista vem exercer sobre discursos de circulação (SCHERER; TASCHETTO, 2005, p. 122).

Nesse sentido, as referidas autoras corroboram com o que defende Pêcheux (1983b) quando afirma que a memória não pode ser vista como reservatório, preenchido com conteúdo homogêneo e bordas transcendentais históricas. Ela necessita, pois, de um espaço móvel de divisões, de disjunções, de deslocamentos, réplicas, polêmicas e contra-discursos.

\section{Estrutura/acontecimento na encíclica Rerum Novarum}

Na encíclica Rerum Novarum, é possível elencar 31 (trinta e um) temas que materializam o discurso da Igreja Católica acerca das relações de trabalho. O enunciador, ao expor seus argumentos, estabelece paralelos que reforçam a ascensão social, a diferença entre os homens e o direito à propriedade privada, temas possíveis de serem verificados na parte introdutória da referida encíclica, quando o Papa Leão XIII, em 1891, descreve o que vem a ser "A sede de inovações":

${ }^{4}$ Termo introduzido por P. Achard na mesma obra em que Pêcheux (1983b) trata da questão da memória. 
(1) A sede de inovações, que há muito tempo se apoderou das sociedades e as tem numa agitação febril, devia, tarde ou cedo, passar das regiões da politica para a esfera vizinha da economia social. Efectivamente, os progressos incessantes da indústria, os novos caminhos em que entraram as artes, a alteração das relações entre os operários e os patrões, a influência da riqueza nas mãos dum pequeno número ao lado da indigência da multidão, a opinião enfim mais avantajada que os operários formam de si mesmos e a sua união mais compacta ${ }_{2}$ tudo isto, sem falar da corrupção dos costumes, deu em resultado final um temível conflito (RN, 1891, p. 1, grifos nossos).

Diante do cenário característico do período marcado pelas consequências da Revolução Industrial, é possível ratificar a posição do enunciador e, consequentemente, da Igreja, aqui materializada linguisticamente por meio das expressões em destaque, com relação ao que vem a ser "A sede de inovações" e o impacto dessas inovações na sociedade. Verificamos que, ao se referir "aos progressos incessantes da indústria”, o excerto materializa o pré-construído ${ }^{5}$ de que houve progressos nas indústrias, momento de profundas transformações na sociedade em meio a revoluções políticas, que já afetavam essa mesma sociedade desde o período das Revoluções Francesa e Inglesa, baseadas em ideias Iluministas. Conforme Beguoci (2009), a referida encíclica "Pode ser considerada a resposta católica ao manifesto comunista e aos movimentos de agitação esquerdista dentro das fábricas da Europa e dos Estados Unidos” (BEGUOCI, 2009, p. 134-135). Nesses movimentos, era possível destacar alguns de seus seguidores como Marx e Engels, os quais já questionavam, à época, a situação dos trabalhadores:

O preço médio que se paga pelo trabalho assalariado é o mínimo de salário, ou seja, a soma dos meios de subsistência necessários para que o operário viva como operário. Por conseguinte, o que o operário recebe como seu trabalho é o extritamente necessário para a

\footnotetext{
5 Termo usado por P. Henry (apud PÊCHEUX, 1975, p. 99) "para designar o que remete a uma construção anterior, exterior, mas sempre independente, em oposição ao que é 'construído' no enunciado”. Segundo Pêcheux, o efeito de pré-construído é "a condição formal de um efeito de sentido cuja causa material se assenta, de fato, na relação dissimétrica por discrepância entre dois 'domínios de pensamento', de modo que um elemento de um domínio irrompe num elemento do outro sob a forma do que chamamos 'pré-construído', isto é, como se esse elemento já se encontrasse ầ" (PÊCHEUX, 1975, p. 99).
} 
mera conservação e reprodução da sua existência [...] (MARX; ENGELS, 1948, p. 53).

Esse fragmento do Maniferto Comunista (1848) demonstra como eram as relações de trabalho antes mesmo da publicação da encíclica Rerum Novarum. Os autores reforçam também como eram as concepções burguesa e comunista a esse respeito.

Na sociedade burguesa o trabalho vivo é sempre um meio de aumentar o trabalho acumulado. $\mathrm{Na}$ sociedade comunista o trabalho acumulado é um meio de ampliar, enriquecer e promover a existência dos trabalhadores (MARX; ENGELS, 1948, p. 53).

Na encíclica Rerum Novarum, verificamos uma estreita relação entre política e economia, pois o enunciador refere-se, no exceto 1, à "sede de inovações", que faz “[...] passar das regiões da política para a esfera vizinha da economia social’. Esse enunciado reforça o que estava ocorrendo no período, vez que essa ligação entre política e economia mostra como se relacionavam os diferentes modos de produção e, consequentemente, como era o embate que se travava politicamente entre capitalistas e socialistas.

Havia, nessa perspectiva, por um lado, a defesa de uma sociedade capitalista, movida pelas ideias do liberalismo econômico ${ }^{6}$; e, por outro, os ideais marxistas e a luta pela

\footnotetext{
${ }^{6}$ Para o liberalismo econômico, que surgiu no final do século XVIII, quando o capitalismo estava avançando na Europa, e cujo principal teórico foi Adam Smith, patrão e operário eram vontades soberanas, que deveriam livremente dispor de seu direito de fixar as regras dos contratos de trabalho relativas ao salário, à duração e às condições do mesmo trabalho.
} 
revolução do proletariado. O enunciador da encíclica, mesmo apresentando algumas críticas a esse sistema capitalista, reforça a sua permanência ao afirmar que "não pode haver capital sem trabalho, nem trabalho sem capital” (RN, 1891, p. 9).

A expressão "a opinião enfim mais avantajada que os operários formam de si mesmos e a sua união mais compacta", retirada da encíclica Rerum Novarum, remete-nos a conceitos abordados por Karl Marx em relação “à classe ${ }^{7}$ proletária”, termo também encontrado na encíclica sob análise como sinônimo de operário, o que produz o pré-construído de que já havia, naquele momento, grupos que se reuniam em torno de ideais comuns, como é o caso da "Liga dos Justos", depois nomeada "Liga dos Comunistas", ou mesmo da "Associação Operária", que emergiu a partir das discussões que giravam em torno da referida liga. Esses movimentos impulsionaram a constituição de sindicatos dos trabalhadores das indústrias, os quais surgiram nesse período.

A formulação "corrupção dos costumes", citada pelo papa, completa o efeito de sentido atribuído anteriormente à união da classe operária, vez que remete às teses socialistas, que circulavam na época, e que consistiam em uma forte ameaça aos padrões apregoados pela Igreja Católica acerca do comportamento que o cristão deve apresentar na sociedade. Essa "corrupção dos costumes" contribuiu, de certa forma, para dissolução da tradição filosófica católica, devido ao choque com a filosofia moderna no campo cultural, o que acabou por introduzir na Igreja as tensões entre capitalismo e socialismo, que já se desdobravam nas estruturas da sociedade civil. A esse respeito, Terra (1991) acrescenta:

A oposição entre a Filosofia moderna e a Fé cristã havia chegado ao limite. Racionalismo, deísmo, agnosticismo, criticismo, idealismo, materialismo, são atitudes filosóficas incompatíveis com a doutrina

\footnotetext{
7 "O $\mathrm{O}$ conceito de classe é muito relevante na teoria marxista, conquanto nem Marx nem Engels jamais o tenham formulado de maneira sistemática. Num certo sentido, ele foi o ponto de partida de toda a teoria de Marx, pois foi a descoberta do PROLETARIADO como 'a idéia no próprio real'. Uma nova força política engajada em uma luta pela emancipação” (DICIONÁRIO DO PENSAMENTO MARXISTA, 2012, p. 61). Ressaltamos também que a burguesia e o proletariado são as duas principais classes trabalhadas pelos autores marxistas no que se refere à sociedade capitalista.
} 
da Igreja. A isto se acrescenta que as idéias da ilustração e a corrente revolucionária que se abateu sobre as nações européias haviam debilitado profundamente a vida religiosa e impedido o cultivo das ciências sagradas [...]. Nessas circunstâncias, se impunha uma renovação do pensamento cristão. Era mister uma confrontação e se possível, uma integração de todos aqueles elementos do pensamento moderno conciliáveis com a verdade cristã (TERRA, 1991, p. 348).

Tudo isso alterou o comportamento e, consequentemente, agiu sobre divisão de grupos dos seguidores do catolicismo, impulsionando pensadores da doutrina católica a elaborarem um conjunto de documentos doutrinais com critérios de ação que acabaram por criar uma conjuntura propícia para elaboração da Rerum Novarum. ${ }^{8}$ Em vários trechos dessa encíclica, há, portanto, vestígios da teoria marxista, vinculada ao materialismo histórico, que surgiu antes mesmo da publicação pela Igreja Católica do seu primeiro documento voltado às questões sociais.

(2) Por certo que a maior parte dos operários queriam melhorar de condição por meios honestos sem prejudicar a ninguém; todavia, não poucos há que, embebidos de máximas falsas e desejosos de novidade, procuram a todo o custo excitar e impelir os outros a violências. Intervenha portanto a autoridade do Estado, e, reprimindo os agitadores, preserve os bons operários do perigo da sedução e os legítimos patrões de serem despojados do que é seu (RN, 1891, p. 21, grifos nossos).

As expressões "máximas falsas", "desejos de novidade”, "excitar e impelir os outros a violências" e "os agitadores” são indícios linguísticos que apontam o lugar da Igreja Católica, a qual, mesmo apresentando em seu texto questionamentos que se relacionam com o que defendia o Marxismo, mostra-se contrária ao posicionamento deste no tocante aos problemas enfrentados pela classe trabalhadora. Verificamos, com isso, que a encíclica é

\footnotetext{
${ }^{8}$ Vale lembrar que, segundo Terra (1991), os Bispos Brasileiros, convocados a Roma por Leão XIII, em 1899, para o primeiro concílio Plenário Latino Americano, contribuíram para que, na legislação brasileira, fosse aplicada a Doutrina Social da Rerum Novarum.
} 
atravessada por diferentes discursos, materializados na/pela língua, por meio de formulações já enunciadas em outros espaços de circulação.

Mesmo condenando a ação de grupos ligados às ideias marxistas, o enunciador recorre ao termo "proletariado", que está intimamente relacionado aos ideais revolucionários do movimento comunista, como sinônimo para operários, a exemplo do seguinte trecho:

O problema nem é fácil de resolver, nem isento de perigos. É difícil, efectivamente, precisar com exactidão os direitos e os deveres que devem ao mesmo tempo reger a riqueza e o proletariado, o capital e o trabalho (Grifo nosso).

Tal deslocamento mostra que, como defende Pêcheux (1983a), o discurso é estrutura e acontecimento, é o resultado de um jogo entre estabilização e desestabilização. Nessa direção, mesmo se opondo ao discurso marxista, o enunciador da encíclica usa termos que fazem parte da semântica do referido movimento.

No que se refere à ideia de "classe", na última parte da encíclica Rerum Novarum constatamos que o enunciador desloca questões de ordem social para o campo religioso, objetivando "estreitar a união das duas classes até as unir uma à outra por laços de verdadeira amizade" (RN, 1891, p. 11). O enunciador defende que, por meio das ações de caridade, é possível se obter uma equidade nas relações entre patrões e operários, diminuindo, assim, a distância entre ricos e pobres. Assumindo, pois, o lugar do Estado", o enunciador da encíclica estabelece as "obrigações dos patrões e operários", a saber:

(3) Entre estes deveres, eis os que dizem respeito ao pobre e ao operário: deve fornecer integral e fielmente todo o trabalho a que se comprometeu por contrato livre e conforme à equidade; não deve lesar o seu patrão, nem nos seus bens, nem na sua pessoa; as suas reivindicações devem ser isentas de violências e nunca revestirem a

\footnotetext{
9 "Conceito de importância fundamental no pensamento marxista, que considera o estado como a instituição que, acima de todas as outras, tem como função assegurar e conservar a dominação e a exploração de classe" (DICIONÁRIO DO PENSAMENTO MARXISTA, 2012, p. 197).
} 
forma de sedições; deve fugir dos homens perversos que, nos seus discursos artificiosos, lhe sugerem esperanças exageradas e lhe fazem grandes promessas, as quais só conduzem a estéreis pesares e à ruína das fortunas[...]. Quanto aos ricos e aos patrões, não devem tratar o operário como escravo, mas respeitar nele a dignidade do homem, realçada ainda pela do Cristão. O trabalho do corpo, pelo testemunho comum da razão e da filosofia cristã, longe de ser um objecto de vergonha, honra o homem, porque lhe fornece um nobre meio de sustentar a sua vida. O que é vergonhoso e desumano é usar dos homens como de vis instrumentos de lucro, e não os estimar senão na proporção do vigor dos seus braços ( $\mathrm{RN}, 1891$, p. 10).

No excerto 3, vemos a materialização de uma visão hierárquica, a qual prevê que os deveres das duas classes devam ser estabelecidos de cima para baixo e definidos por uma instituição que esteja acima das duas classes, daí viria a equidade entre as classes. Com isso, o enunciador reafirma uma importante função do Estado em sua associação com a classe economicamente dominante, que é justamente regular a luta de classes e assegurar a estabilidade da ordem social. Isso vai de encontro à forma como os comunistas vêem a solução para os problemas trabalhistas, tendo em vista que defendem a luta de classes dentro da revolução operária, como alternativa para construção de uma sociedade igualitária.

\section{Centesimus Annus: efeitos de sentido, memória e acontecimento}

Com base no que Pêcheux (1983a) mostra acerca dos universos irremediavelmente equívocos, defendemos aqui que o discurso religioso funciona como um universo irremediavelmente equívoco. Isso porque, faz parte da constituição do discurso religioso a existência de uma tensão na construção dos diferentes efeitos de sentido, os quais se constituem por meio de uma relação conflituosa entre língua e história. Faremos, dessa forma, uma análise da encíclica Centesimus Annus, promulgada em $1^{\circ}$ de maio de 1991 , pouco tempo após a queda do Muro de Berlin, procurando mostrar o acontecimento discursivo a partir do acontecimento histórico, que é aqui analisado com base nos aspectos históricos sob os quais essa encíclica foi elaborada. A esse respeito, vejamos o seguinte fragmento: 
(4) Desejo agora propor uma "releitura" da Encíclica leonina, convidando a "olhar para trás", ao próprio texto, para descobrir de novo a riqueza dos princípios fundamentais, nela formulados, sobre a solução da questão operária. Mas convido também a "olhar ao redor", às "coisas novas", que nos circundam e em que nos encontramos como que imersos, frequentemente muito diversas das "coisas novas" que caracterizaram o último decênio do século passado. Enfim, convido a "olhar ao futuro", quando já se entrevê o terceiro Milénio da era cristã, carregado de incógnitas, mas também de promessas. Incógnitas e promessas que apelam à nossa imaginação e criatividade, estimulando também a nossa responsabilidade, como discípulos do "único Mestre", Cristo (cf. Mt 23, 8), de indicar o "caminho", proclamar a "verdade" e comunicar "a vida" que é Ele próprio (cf. Jo 14, 6) (CA, 1991, p. 3).

Ao propor "olhar para trás" e ao mesmo tempo para as "coisas novas", o enunciador faz a junção do passado (Rerum Novarum) com o presente (Centesimus Annus), mostrando que há uma relação entre as duas encíclicas. Essa relação encontra-se materializada na língua por meio de construções sintáticas, como “descobrir de novo”, oxímoro que estabelece um jogo entre novo (descobrir) e velho (de novo/novamente); de pré-construídos os quais mostram linguisticamente que, muitas vezes, o que aparece como verdade na Centesimus Annus foi construído antes e em outro lugar. É o que ocorre no caso de construções como: “a riqueza dos princípios fundamentais", que institui o referente, marcado pela expressão referencial definida, como algo de existência real, logo, como algo inquestionável; ou, para citar outro exemplo, “a solução da questão operária”, que, por um efeito do pré-construído, apresenta a questão operária como algo que tem solução.

A relação intertextual com a Rerum Novarum funciona como um indício que mostra que ambas as encíclicas são atravessadas pelas mesmas relações interdiscursivas. Nesse sentido, quando convida seu coenunciador a olhar "as coisas novas", o enunciador estabelece uma relação intertextual com a Rerum Novarum, pois, como dito anteriormente, uma tradução possível para Rerum Novarum é, justamente, "das coisas novas”.

No entanto, para além da relação intertextual, há o estabelecimento de uma relação interdiscursiva que faz com que as relações de trabalho sejam vistas, no interior desse interdiscurso, como uma "coisa nova". Há um jogo entre memória e atualidade, pois só é 
possível ao coenunciador ler/interpretar os efeitos de "coisas novas" na Centesimus Annus se ele "compreende" a que se refere à expressão "das coisas novas" na encíclica Rerum Novarum. E, para isso, é preciso mais que "decifrar" uma simples relação entre textos, é necessário ser/estar sujeito de/a um determinado discurso. É por isso que o enunciado “como discípulos do 'único mestre', Cristo (Mt 23, 8)" também funciona como um préconstruído, o qual mostra a que coenunciador o texto em tela se remete: trata-se de um coenunciador para o qual Cristo é o "único mestre", ou seja, trata-se do cristão. É para ele que tanto a Rerum Novarum quanto a Centesimus Annus foram escritas.

A expressão “Desejo agora propor uma 'releitura' da Encíclica leonina”, convidando a "olhar para trás", indica que o enunciador Papa João Paulo II não é o responsável pelo enunciado apresentado na sequência do texto, embora tenha se apoiado nesse outro texto para apresentar o seu posicionamento. Isso pode ser constatado, também, na escolha de citações indiretas, ou por meio do resumo com citações, que também constitui um modo de discurso relatado ${ }^{10}$, como no exemplo a seguir:

(5) [...] o Papa [Leão XIII] enuncia um outro direito do operário como pessoa. Trata-se do direito ao "justo salário", que não pode ser deixado "ao livre acordo das partes: de modo que o dador de trabalho, uma vez paga a mercadoria, fez a sua parte, sem de nada mais ser devedor". O Estado, não tem poder - dizia-se naquele tempo - para intervir na determinação destes contratos, mas apenas para garantir o cumprimento de quanto fora explicitamente estipulado (CA, 1991, p. 8).

Nesse caso, o ponto de vista considerado é do enunciador da encíclica Rerum Novarum, ou seja, do discurso citado e não do discurso citante. Essa constatação é possível por

${ }^{10}$ Esse tipo de discurso relatado, consoante Maingueneau (2008, p. 154), "é geralmente marcado por itálico e aspas. Trata-se do resumo de um texto, cujo original aparece apenas em fragmentos no fio do discurso". 
conta do início do excerto, quando é dito que "o Papa enuncia um outro direito do operário". O verbo "enunciar" indica ser realmente Leão XIII quem fez as afirmações que estão entre aspas.

Sobre o final do fragmento em destaque, observamos que o enunciador da Centesimus Annus utilizou-se do recurso da paráfrase para descrever qual deve ser o posicionamento do Estado diante da questão da remuneração dos trabalhadores, vez que empregou palavras similares às utilizadas na encíclica Rerum Novarum, atestando, pois, ter o mesmo direcionamento discursivo desta.

Embora na citação feita pelo enunciador da Centesimus Annus em referência à encíclica Leonina, haja um apagamento das vozes ${ }^{11}$ dos enunciadores das respectivas encíclicas por conta da expressão "dizia-se", constatamos que os efeitos de sentido dos dois documentos mantêm relação um com o outro, por um efeito da memória sobre a atualidade. Isso ocorre em relação ao posicionamento do Estado no que diz respeito à questão salarial, isto é, à concepção de que o Estado não deveria intervir nas questões de ordem trabalhista, apenas se manifestar caso alguns dos direitos dos patrões ou dos operários fossem violados. Esse posicionamento, que vai sendo cristalizado ao longo da história do centenário da Rerum Novarum, é recuperado na memória por um lugar institucional, aqui representado pela Igreja Católica.

Ao descrever, no capítulo V, cujo título é "Estado e Cultura", o mesmo dever do Estado para com os trabalhadores, presente na primeira encíclica aqui discutida, verificamos que, como defende Pêcheux (1983b), o acontecimento foi absorvido como se não tivesse ocorrido. Contrapondo-se ao conceito de Estado apresentado pelos grupos socialistas, que permaneceram em algumas superpotências por um longo período, como no caso da União Soviética, o enunciador retoma o mesmo posicionamento adotado na época da Rerum Novarum, ao afirmar que "Outra tarefa do Estado é a de vigiar e orientar o exercício

\footnotetext{
11 "Foi M. Bakhtin, linguista russo, quem introduziu essa noção para o estudo da literatura romanesca; a partir de então, ela vem sendo utilizada na linguística para analisar os enunciados nos quais várias 'vozes' são percebidas simultaneamente" (MAINGUENEAU, 2008, p. 138).
} 
dos direitos humanos, no sector económico; neste campo, porém, a primeira responsabilidade não é do Estado, mas dos indivíduos e dos diversos grupos e associações em que se articula a sociedade" (CA, 1991, p. 48). Ao trazermos para análise a relação entre memória e discurso, verificamos a existência de um interdiscurso, o qual reforça a ideia de retomada daquilo já visto de alguma forma, em outro espaço de memória, ou seja, "é preciso que o que foi dito por um sujeito específico, em um momento particular, se apague na memória para que, passado para o 'anonimato', possa fazer sentido em minhas palavras" (ORLANDI, 1999, p. 33-34). Dessa forma, quando o enunciador da Centesimus Annus diz qual deve ser o papel do Estado, no capítulo $V$ da encíclica em questão, mesmo sem fazer menção à Rerum Novarum, reconstituímos, via memória, conceitos já cristalizados na/pela Igreja Católica.

Nesse mesmo capítulo, o enunciador professa que "Infelizmente ainda hoje é freqüente encontrar casos de contratos entre patrões e operários, nos quais se ignora a mais elementar justiça, em matéria de trabalho [...] e da legitima retribuição" (CA, 1991, p. 8, grifos nossos). O uso da fórmula "ainda hoje", que tem como ponto de referência o momento da enunciação dessa encíclica, revela a permanência de uma dada situação que perdurou por cem anos, e que, mesmo após o centenário da Rerum Novarum, ainda é possível de ser encontrada.

A expressão "ainda hoje" institui o pré-construído de que, antes mesmo da Centesimus Annus, ainda na época da Rerum Novarum, era possível encontrar esse mesmo quadro vivido pela classe trabalhadora, a saber,

[...] que os patrões esmagam os trabalhadores sob o peso de exigências iníquas, ou desonram neles a pessoa humana por condições indignas e degradantes; que atentam contra a sua saúde por um trabalho excessivo e desproporcionado com a sua idade e sexo (RN, 1891, p. 20, grifo nosso). 
Comprovamos que alguns enunciados da encíclica Rerum Novarum, bem como de obras que remetem às materialidades sócio-históricas em que esta foi promulgada, funcionam como pré-construídos na encíclica Centesimus Annus, o que aponta

esse discurso-outro, enquanto presença virtual na materialidade descritível da sequência, marca, do interior desta materialidade, a instância do outro como lei do espaço social e da memória, logo como o próprio princípio do real sócio-histórico (PÊCHEUX, 1983a, p. 55).

Na II parte da Centesimus Annus, cujo título é "Rumo às 'coisas novas' de hoje”, o enunciador refere-se aos fatos que se constituíram diante da nova conjuntura e que insurgiram mediante um acontecimento que marcou o final da década de 1980 e início dos anos 1990, a saber, a derrocada do regime comunista, representada simbolicamente pela queda do Muro de Berlin; bem como a terceira Revolução Industrial, baseada em novas tecnologias e no processo de globalização, conforme atesta a referida encíclica:

(6) A comemoração da Rerum Novarum não seria adequada, se não olhasse também à situação de hoje. Já no seu conteúdo, o Documento se presta a uma tal consideração, porque o quadro histórico e as previsões, aí delineadas, se revelam, à luz de quanto aconteceu no período sucessivo, surpreendentemente exactas. Isto foi confirmado de modo particular pelos acontecimentos dos últimos meses do ano de 1989 e dos primeiros de 1990. Estes e as consequentes transformações radicais só se explicam com base nas situações anteriores, que em certa medida tinham materializado e institucionalizado as previsões de Leão XIII e os sinais, cada vez mais inquietantes, observados pelos seus sucessores. Aquele Pontífice, com efeito, previa as consequências negativas, sobre todos os aspectos - político, social e económico - de uma organização da sociedade, tal como a propunha o "socialismo", que então estava ainda no estado de filosofia social e de movimento mais on menos estruturado. Alguém poderia admirar-se do facto de que o Papa começasse pelo "socialismo", a crítica das soluções que se davam à "questão operária", quando ele ainda não se apresentava (CA, 1991, p. 12, grifos nossos). 
O enunciador, no excerto 6, retoma a encíclica Rerum Novarum e apresenta-a como uma carta que faz "previsões" em relação às consequências supostamente nefastas do socialismo no mundo. De acordo com tal interpretação, tudo que foi dito na Rerum Novarum é apresentado como uma espécie de verdade prefigurada pela igreja. Essa memória só é possível porque há um jogo com a atualidade, marcada pela queda do regime comunista em muitos países.

Vê-se, pois, pela incidência do termo "coisas novas" (item lexical), retomado várias vezes na encíclica, que

a repetição é antes de tudo um efeito material que funda comutações e variações, e assegura - sobretudo ao nível da frase escrita - o espaço de estabilidade de uma vulgata parafrástica produzida por recorrência, quer dizer, por repetição literal dessa identidade material (PÊCHEUX, 1983b, p. 53).

Apoiando-nos, então, nos conceitos de Pêcheux (1983b), constatamos que a materialidade léxico-sintática da expressão “coisas novas” é profundamente opaca, pois imerge em uma rede de relações associativas implícitas, vez que é formada por um substantivo, o qual produz uma ideia de indefinição (coisas) e generaliza uma série de fatos que se passavam naquele período.

Nesse caso, para entender o significado dessa expressão, é preciso, por meio da Análise de Discurso, “interrogar os efeitos matérias de montagens de sequências, sem buscar a princípio e antes de tudo sua significação ou suas condições implícitas de interpretação" (PÊCHEUX, 1983b, p. 53-54). No caso das duas encíclicas, a Rerum Novarum e a Centesimus Annus, “as coisas novas” estão relacionadas aos acontecimentos que impulsionaram a elaboração das duas encíclicas sob análise e que ocorreram, respectivamente, em torno dos anos de 1891 e 1991.

A questão da luta de classes aparece também na encíclica Centesimus Annus de forma a retomar os conceitos abordados na Rerum Novarum. Essa retomada se dá por meio dos 
pré-construídos, num jogo entre conceitos do passado e do presente que circulam num espaço de memória. A esse respeito, vejamos o excerto abaixo:

(7) Da mesma raiz ateísta, deriva ainda a escolha dos meios de acção, própria do socialismo, que é condenada na Rerum Novarum. Trata-se da luta de classes. O Papa - entenda-se! não pretende condenar toda e qualquer forma de conflitualidade social. A Igreja sabe bem que, ao longo da história, os conflitos de interesses entre diversos grupos sociais surgem inevitavelmente, e que, perante eles, $o$ cristão deve muitas vežes tomar posição decidida e coerente (CA, 1991, p. 14, grifos nossos).

A expressão "luta de classes" é introduzida como retomada de "meios de ação próprios do socialismo". Dessa forma, a luta de classes é definida, na encíclica, como um meio de ação do socialismo, o que retoma uma memória acerca do referido termo, vez que o próprio materialismo histórico define a luta de classes como sendo a base do marxismo prático. A expressão aparece, no discurso materializado na/pela encíclica Centesimus Annus, como algo negativo, por isso "o cristão deve muitas vezes tomar posição decidida e coerente" (CA, 1991, p. 14). O termo "luta de classes" foi sendo substituído, ao longo das várias encíclicas que homenagearam a Rerum Novarum, por outros, como: "conflitos de interesses", "luta pela justiça social" e "honesta discussão fundada na busca da justiça". Nenhuma dessas expressões corresponde exatamente ao efeito de sentido de luta de classes para o movimento marxista. São todas formas de retomada/reconfiguração da referida expressão no interior do discurso religioso, o que mostra que a primeira definição de discurso de Pêcheux (1969), a saber, discurso é efeito de sentido entre locutores, entendidos como lugares na estrutura social, continua válida, pois o efeito de sentido de "luta de classes" muda de acordo com o lugar de onde se fala: o lugar de marxista ou o lugar de cristão. O que Pêcheux (1969) ainda não tinha mostrado, no final da década de 1960, é que esses diferentes efeitos de sentido estão relacionados. Portanto, o efeito de sentido de "luta de 
classes" se dá na relação entre os diferentes lugares discursivos que retomam/reconfiguram essa expressão. Não é só “isso” ou só “aquilo”, mas isso e aquilo ao mesmo tempo, numa relação constitutivamente conflituosa.

\section{Considerações finais}

A indagação apresentada preliminarmente neste artigo refere-se a quais discursos sobre trabalho encontram-se materializados nas Encíclicas Rerum Novarum e Centesimus $A n$ nus? Para responder a essa questão, inscrevemo-nos, teórica e metodologicamente, na perspectiva da Escola Francesa de Análise de Discurso, desenvolvida por Pêcheux. Tal perspectiva possibilitou-nos alguns construtos teóricos para analisar a relação entre acontecimento e memória nas relações de trabalho.

Nas análises, verificamos que os acontecimentos discursivos que, de certa forma, impulsionaram a elaboração desses dois documentos, a saber, efervescência das ideias comunistas, em 1981, e a queda do Muro de Berlin, em 1989, evento considerado por alguns discursos como símbolo da derrocada do comunismo, aqui descritos como "as coisas novas", são o resultado de uma memória discursiva. Nessa perspectiva, os dados aqui analisados confirmam a hipótese que sustenta este artigo: a de que Centesimus Annus (1991) retoma os discursos materializados na Rerum Novarum e atualiza esses discursos por meio de um jogo entre memória e atualidade, que se configura "num espaço de desdobramento, réplicas, polêmicas e contra-discursos" (PÊCHEUX, 1983b, p. 52). Nessa perspectiva, constatamos que os discursos materializados nesses documentos refletem a forma hierárquica como o enunciador Igreja Católica pensa a sociedade e, consequentemente, as relações de trabalho. Observamos, por meio da caracterização das duas encíclicas, que tanto o discurso capitalista quanto o discurso comunista encontram-se materializados em ambos os textos e passam a ser atravessados por concepções religiosas/cristãs/católicas, as quais, em certa medida, estão vinculadas à ideologia capitalista burguesa. 


\title{
THE ENCYCLICALS RERUM NOVARUMAND CENTESIMUS ANNUS: A DISCURSIVE ANALISIS ABOUT THE WORK ISSUE
}

\begin{abstract}
:
In this paper, we aimed to verify which discourses about work are materialized in the encyclicals Rerum Novarum and Centesimus Annus. We based on the following hypothesis: the Centesimus Annus, written in 1991, that honors the Rerum Novarum and it was promulgated in 1891, recovers discourses about the materialized work in the Rerum Novarum and updates these discourses by the relation between memory and event. We presented a survey about the concepts of event and discursive memory, according to Pêcheux (1983a, 1983b). Along the theoretical discussion and analysis, we also took up concepts of Marx and Engels (1948); Taschetto and Scherer (2005); and Terra (1991).
\end{abstract}

KEYWORDS: Religious Discourse; Encyclicals; Memory; Work.

\section{REFERÊNCIAS}

BEGUOCI, Leandro. Atestado progressista. VEJA, São Paulo: Editora Abril, n. 2121, p. 134-135, 15 jul. 2009. Disponível em: <http://www.veja.com/acervodigital/home.aspx>. Acesso em: 11 ago. 2012.

CARTA ENCÍCLICA CENTESIMUS ANNUS DO SUMO PONTÍFICE JOÃO PAULO II. Roma, 1991. Disponível em: <http://www.vatican.va/holy_father/john_paul_ii/encyclicals/documents/hf_jpii_enc_01051991_centesimus-annus_po.html>. Acesso em: $1^{\circ}$ ago. 2012.

CARTA ENCÍCLICA RERUM NOV ARUM DO PAPA LEÃO XIII SOBRE A CONDIÇÃO DOS OPERÁRIOS. Roma, 1891. Disponível em: <http://www.vatican.va/holy_father/leo_xiii/encyclicals/documents/hf_l-xiii_enc_15051891_rerum-novarum_po.html>. Acesso em: $1^{\circ}$ ago. 2012.

DICIONÁRIO DO PENSAMENTO MARXISTA. Editado por Tom Bottomore; coeditores: Laurence Harris, V. G. Kiernan e Ralph Miliband. Tradução: Waltensir Dutra. 2. ed. Rio de Janeiro: Zahar, 2012.

HENRY, Paul. Os fundamentos teóricos da "análise automática do discurso" de Michel Pêcheux (1969). In: PÊCHEUX, Michel. Por uma análise automática do discurso. Uma introdução à obra de M. Pêcheux. 4. ed. Campinas: Editora da Unicamp, 2010. Edição Original: 1969. p. 11-38.

MAINGUENEAU, Dominique. Análise de textos de comunicação. Tradução de Cecília P. de Souza-e-Silva e Décio Rocha. 5. ed. São Paulo: Cortez, 2008. 
MARX, Karl; ENGELS, Friedrich. Manifesto Comunista. Organização e introdução: Osvaldo Coggiola; tradução do Manifesto Álvaro Pina e Ivana Jinkings. 1. ed. revista. São Paulo: Boitempo, 2005. Edição Original: 1848.

ORLANDI, E. Análise de Discurso: princípios e procedimentos. 7. ed. Campinas: Pontes, 2007. Edição Original: 1999.

PÊCHEUX, Michel. Por uma análise automática do discurso. Uma introdução à obra de M. Pêcheux. 4. ed. Campinas: Editora da Unicamp, 2010. Edição Original: 1969.

. Estrutura ou Acontecimento. Tradução de Eni Puccinelli Orlandi. 4. ed. Campinas: Pontes Editores, 2006. Edição Original: 1983a.

. Papel da memória. In: ACHARD, P. et al. Papel da memória. Trad. José Horta Nunes. 2. ed. Campinas: Pontes, 2007. Edição Original: 1983 b.

SCHERER; A. E; TASCHETTO, T. R. O papel da memória ou a memória do papel de Pêcheux para os estudos linguísticos-discursivos. Estudos da Lingua(gem), Vitória da Conquista: Edições UESB, n. 1, p. 119-123, jan./jun. 2005.

TERRA, D. João Evangelista. A Rerum Novarum dentro de seu contexto sociocultural. Síntese Nova Fase, São Paulo: Edições Loyola, v. 18, p. 347-366, jul./set. 1991.

Recebido em: 12/07/2017.

Aprovado em: 03/11/2017. 